Vol. 1, No. 2

Vitoria - ES, Jun - Dec. $2004 \quad$ DOI: http://dx.doi.org/10.15728/bbr.2004.1.2.5

p. $136-150$

\title{
Ohlson Model Testability: Empirical Tests Findings ${ }^{i}$
}

\author{
César Medeiros Cupertino \\ Brasília University
}

\author{
Paulo Roberto Barbosa Lustosa \\ Brasília University
}

\begin{abstract}
This paper analyses the empirical testability of Ohlson Model (OM). The methodology used comprises: (i) exploratory research with regards to the study objective; (ii) bibliography research with regards to the applicable procedures; and (iii) qualitative research with regards to problem approach. Literature research has comprised both origin (dividend discount, assessment of residual income etc) and the model subjacent theory. The linear information dynamics (LID) and the assessment formulae were discussed concerning the model internal consistency, as well as the establishment of the required inputs (parameters and variables). Empirical studies have been analyzed both in terms of their structuring and their achieved results. The study has concluded that: (1) no consensus has yet been achieved over the appropriate way to measure the parameters of persistency; (2) doubts as to the appropriate way of capturing the parameters $\omega$ and $\gamma$, and the variable $v$ prevents verification of the effective explanatory capabilities of the Ohlson Model; (3) empirical testability is limited to absences of consistent proxies that may capture persistency and previsibility of the institution's future income.
\end{abstract}

Key- Words: Valuation, Ohlson Model, empirical testing

César Medeiros Cupertino

Doutor em Engenharia de Produção

Universidade Federal de Santa Catarina,

UFSC, Brasil.

Adress: Av. Gov. Irineu Bornhausen, 4744,

Centro, 88025-201 - Florianopolis, SC - Brazil

Email: cupertino.cmc@gmail.com

Telephone: (48) 32816595
Paulo Roberto Barbosa Lustosa

Doutorado em Controladoria e Contabilidade

A Universidade de Brasília UNB

Adress: Asa Norte - 70910900 - Brasília, DF -

Brazil

Email: prblustosa@gmail.com

Telephone: (061) 31070895

\footnotetext{
${ }^{\mathrm{i}}$ This paper was presented in the 4th Controlling and Accounting USP Congress
} 


\section{FOREWORD}

V aluation is one of the main topics of the capital market research (KOTHARI, 2001). Bodie and Merton (2002) and Damodaran (1999) emphasized that the ability to precisely valuate assets is the core of finance theory since many personal and corporate decisions may be done through choice of alternatives that maximize value. Fernandez (2001) asserts that valuation may be used for several purposes and among them, it can be used: to determine the IPO initial share value (Initial Public

Offering); to serve as a comparison parameter for the negotiation of shares in the stock market; to quantify value creation that is attributable to corporate businessman (for bonuses purposes), to help in the strategic decision making (decision to continue in business, to sell, to expand, to merge or to acquire other companies).

A series of relevant issues may be taken into account on an investment valuation: market efficiency, analyst forecast and opportunity cost are among them. In some models, there were attempts to understand the interaction of these issues in valuation formula, with methodological approaches that vary in terms of level complexity ${ }^{\text {ii }}$ In this respect, Ohlson (1995) presented formulae that derived from these classic conceptions and that used accounting variables in the valuation function. Such structuring was called Ohlson Model $(\mathrm{OM})$ and had great impact in the capital market academic research.

Despite the model widespread discussion in the foreign literature, Ohlson Model is still a developing issue in Brazil (LOPES, 2001). Except for some papers which have a predominant qualitative approach and that in the large majority do not take into account what is the most innovative issue in the model: the linear information dynamics premise. In this sense, this paper carries on an incursion in Ohlson Model with the purpose to enable a better understanding of what it represents and the way variables interact in the valuation function.

The remainder of the study is organized as follows: section 2 offers a theoretical fundamentation, section 3 describes the applicable methodology, section 4 focuses Ohlson Model (structuring the required inputs); section 5 demonstrates the model's empirical tests and section 6 concludes the paper.

\section{THEORETICAL FUNDAMENTATION}

The finance theory describes valuation in terms of the expected future dividends (PENMAN; SOUGIANNIS, 1998), being the dividend discount model (DDM) the basic and theoretically correct valuation approach (PLENBORG, 2000). Its formal representation is given by:

$$
p_{t}=\sum_{\tau=1}^{\infty} R^{-\tau} E_{t}\left(\tilde{d}_{t+\tau}\right)
$$

Where:

$p_{t}$ is the company's market value at $t$;

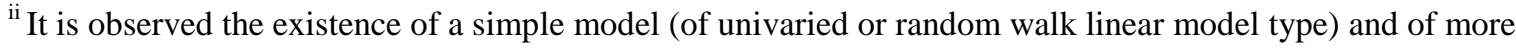
sophisticated models (of multivaried or multiorder auto-regressive process types).
}

BBR, Braz. Bus. Rev. (Eng. ed., Online),

Vitória, v. 1, n. 2, Art. 5, p.136 - 150, jun.- dec. 2004

www.bbronline.com.br 
$\tilde{d}_{t+\tau}$ is the net dividend assumed represented at $t+\tau$;

$R$ is the discount rate $r$ (free risk rate) plus " 1 ", denominated as a constant;

$E_{t}$ means the trader's expectation based on available data at $t$.

The formula focuses the valuation issue in the investors' outlook: when he purchases part of the company's net equity, the investor expects to receive dividends related to this portion. The amount of the portion it owns must be the same as the dividend cash flow present value (ANG; LIU, 1998). With this structure, the DDM is the main traditional focus for valuation in the economic and finance literature (ANG; LIU, 1998), being used as a fundament in the formulation of other models, i.e., the residual income valuation (RPV). For Lo and Lys (2000), RPV lies in the simple hypothesis that the enterprise value is the present value of all future dividends.

The residual income valuation was largely ignored in the specialized literature. Its revival therefore represents the greatest contribution to the modern accounting (LUNDHOLM, 1995). Through the use of income, the book value of the NE (Net Equity) in relation to the Clean Surplus, DDM is re-written as a discount model of accounting figures. In its broader form, the model expresses company value as a sum of its capital expenditures and the discounted present value of the residual income of its future activities. Thus,

$$
p=b+\sum_{t} R_{-\tau} E \underbrace{}_{t}\left(x_{a}\right)
$$

where:

$b_{t}$ is assumed to represent the NE book value at $t$;

$x_{t+\tau}^{a}$ expresses the residual income in the period $t+\tau$.

Equation (2) shows that company value may be split into two: an accounting measure of the invested capital $-b_{t}$ - and the measure of the expected residual income amount $\sum_{\tau=1}^{\infty} R^{-\tau} E_{t}\left(x_{t+\tau}^{a}\right)$. This last portion is defined as the cash flow present value of the future economic results that have not yet been incorporated in the current net equity book value. If a firm gets future results at the same rate of the required remuneration of capital (represented by the discount rate $r$ ), then the future residual income present value will be zero. In other words, to the companies that do not create value nor destroy value, the relevant variable to valuation will only be its net equity book value.

By the same token, the residual income in period $t$ is defined as the amount the company earns in excess to the applicable discount rate over the NE book value in the previous period $(t-1)$. The terminology was motivated by the concept that the "normal" income must be related to the "normal" return over the invested capital in the beginning of the period, that is, to the NE book value at " $t-1$ " (OHLSON, 1995). Thus, the "residual" income is interpreted as an income ${ }^{\text {iii }}$ less the burden for capital use.

$x_{t}^{a}=x_{t}-r\left(b_{t-1}\right)$

Where $r$ is the discount rate and $x_{t}$ is the accounting profit $(t-1, t)$.

\footnotetext{
${ }^{\mathrm{iii}}$ In this case, broad or comprehensive income.
} 
As described aforementioned, the concept imposed by equation (3) enables to conclude that a positive result of a residual income indicates a profitable period to the company, since the rate of the accounting return exceeds the company's enterprise cost of capital.

To derive the RPV and the DDM, two additional premises will be necessary (LO;LYS, 2000). The first is the adoption of an accounting system that satisfies the Clean Surplus (Clean Surplus Relation - CSR) Relation. The CSR is a restriction to the relation between the accounting profit $(x)$, the NE book value $(b)$ and the net dividends $(d)$ in the period $t$ (Myers, 1999). In essence, CSR is a condition imposed in order that all equity variation effect is incorporated in the results. Its mathematical notation is:

$$
b_{t}=b_{t-1}+x_{t}-d_{t}
$$

This income representation is a major step over the previous structures (LUNDHOLM, 1995). The formula links income to NE book value in the same equation and implies that the goodwill is equal to the expected future residual income present value (OHLSON, 1995). A consequence of the RPV adoption is its independence in relation to a specific accounting system. Given the future dividends cash flow, the amounts of $b_{t}$ and of $x_{t}$ may be taken by any random numbers. Such assertion is supported by the fact that $b_{t}$ is updated according to equation (4) and the valuation ratio in equation (2) will account for the dividend cash flow present value (DECHOW et al., 1999, p. 4).

The second premise to derive RPV from the DDM is a regularity condition that imposes that the NE book value grows at a lower $R$ rate.

$$
R_{t}^{-\tau} E_{t+\tau}\left(b_{t}\right)-\stackrel{\tau \rightarrow \infty}{\longrightarrow} 0
$$

The RPV model links companies' valuation to observable accounting data, besides resting itself in simple mathematical structures (LO, LYS, 2000). The study carried out by Ohlson (1995) characterizes a residual income model similar to RPV. Despite the fact that the original RPV has come a few decades before the Ohlson Model, Ohlson offers the possibility to rearrange the accounting research focus over company's valuation, thus establishing a formal link among RPV and the propositions provided by an additional structure denominated linear information dynamics (LID)

\section{METHODOLY AND DATA SOURCE}

Regarding the purposes, this paper falls within the scope of the exploratory research. Beuren $(2003$, p. 80$)$ one seeks with an exploratory study, "[...] to better understand the topic, so as to make it clear [...]" and he adds: "[...] to explore a subject means to acquire more knowledge [...], as well as to search for new dimensions not yet known." (BEUREN, 2003, p. 81). Pinsonneault e Kraemer (1993 apud HOPPEN et al., 1996) emphasize that the exploratory research is an elucidating way to analyze new concepts. The study maintains such guidance: it covers a subject that has not yet been explored in the domestic literature and critically analyzes the model regarding its applicability and empirical testability. 
The procedures have used the bibliographic research. Cervo and Bervian (1983) show that the bibliographical research:

[...] explains a problem from the published theoretical references of documents. It may be carried out either independently or as part of the descriptive and experimental research. In both cases they seek to understand and analyze existing past cultural or scientific contributions over a given topic, theme orissue.

In the bibliographical research, all published reference is used as a consultation source: periodic papers, magazines, books, thesis etc (BEUREN, 2003). Due to the scarce domestic literature on Ohlson Model, the research has based itself essentially in foreign literature, notably in periodic papers ${ }^{\text {iv }}$ and books. Additionally, a survey has been carried out in the internet comprising the theme's key words ${ }^{\mathrm{v}}$.

With regards to the problem, the paper falls in the scope of the qualitative research. Beuren (2003, p. 92) emphasizes that:

In the qualitative research deeper analysis was conceived in relation to the phenomena now being studied. The qualitative approach seeks to point out for the non-observed characteristics through a quantitative study, in view of the superficiality of the latter.

Van Maanen (1983 apud HOPPEN et al., 1996) enlightens that the qualitative methodologies are comprised by a set of interpretative techniques. Hoppen et al. (1996) advocate that the qualitative research is complex since it is based in words and not in figures. Richardson (1999) points out that the difference between the qualitative and quantitative research is that the latter uses statistical instruments as fundament for the problem analysis process, while the former does not have this call.

\section{OHLSON MODEL}

\subsection{Model Structuring}

Considering the existing theory, Prof. James Ohlson has envisaged the possibility of structuring a model supported by the relation of CSR, where the accounting variables have a noteworthy role. He has guided himself in the valuation model of the residual income and determined 3 premises: (i) the DDM determines market value, taking into consideration the risk neutrality; (ii) a traditional accounting is used to meet CSR needs; (iii) the Ohlson Model defines the stochastic behavior of $x^{a}{ }_{i}$ In (i), the premise considers the use of the discounted future dividends present value together with the irrelevance property of dividends to define the stock price. In (ii), formula (4) secures the consistency of income determination, regardless of the adopted accounting system.

For $x_{t}^{a}$ stochastic behavior some considerations apply. Ohlson (1995) and Lundholm (1995) emphasize that the empirical implications of the model critically depend of this last

\footnotetext{
iv The periodic papers included in the research are the following, among others: Contemporary Accounting Research; Journal of Finance; The Accounting Review; Journal of Accounting, Auditing and Finance; Journal of Accounting and Economics; Journal of Accounting Research; Journal of Business.

$\checkmark$ Some of the terms looked into were: Residual Income Valuation; Linear Information Model; Linear Information Dynamics; Ohlson Model; Edwards-Bell-Ohlson; EBO.
}

BBR, Braz. Bus. Rev. (Eng. ed., Online), 
premise, related to the informational dynamics of residual income. Its function is to put restrictions on the dividends discount standard model. Seen from an empirical point of view, the company continues to be valued by the DDM, and the nature of the current information ratio and the future dividends discounted value will be established as a differential. The stochastic process that defines the third premise is perceived as a Linear Information Dynamics and is given by the following equations:

$$
\begin{gathered}
\sim_{a}=\omega x_{t}+v_{t}+\tilde{\varepsilon}_{1, t+1} \\
\tilde{\tau}_{t+1}=\gamma \nu_{t}+\sim_{2, t+1}
\end{gathered}
$$

where $x_{t}^{a}$ is the abnormal income (or residual income) for period " $t$ "; $v_{t}$ means "other information" over expected future residual income that are observed in the final " $t$ " period but that have not yet been recognized by the accounting; $\omega$ and $\gamma$ are persistent parameters ; $\Sigma_{1}$ and $\varepsilon_{2}$ represent the stochastic errors, assumed to have normal distribution and zero average.

The LID represents a major contribution of Ohlson for the company valuation research (FUKUI, 2001). Its structure is based in the presumption that the information over future residual income are achieved both by the abnormal income past series and the data not yet accounted for by the accounting (MCCRAE; NILSSON, 2001). The two dynamic equations are combined with the CSR to secure that all data are relevant events related to the company value, and are absorbed by the profits and NE book value (OHLSON, 1995). It is assumed that $x_{t}^{a}$ and $v_{t}$ follow an autoregressive process of only one interval and that the persistence parameters $-\omega$ and $\gamma$-are restricted since they are negative and less than 1 .

With regards to "Other information", Lundholm (1995) teaches us that they relate to non accounting information that provides a shock in the residual income of future periods. Ohlson (1995) assumes that $v_{t}$ should be considered as a summary of relevant events for company valuation that will still cause impact over the financial income. Based on the RPV and in equations (5) and (6), Ohlson has the following valuation function:

$$
p_{t}=b_{t}+\alpha_{1} x_{t}^{a}+\alpha_{2} v_{t}
$$

Where $\alpha_{1}=\frac{\omega}{(R-\omega)}$ e $\alpha_{2}=\frac{R}{(R-\omega)(R-\gamma)}$.

With these structures, Ohlson imposes an additional structure in RPV so that the valuation may be expressed as a function of current account data and not only in forecasts (LEE, 1999 e LO; LYS, 2000). Differently form some other traditional models (DDM and Discounted Cash Flow), Ohlson's valuation formula - given by equation (7) - does not require explicit forecast on future dividends nor on additional terminal value computation premises (DECHOW et al., 1999).

Two observations related to the coefficients $\alpha_{1}$ and $\alpha_{2}$ will help to understand the model's functionality. For $\omega>0$, two coefficients are positive simply because the forecasts $E_{t}\left[\tilde{x}_{t+\tau}^{a}\right]$, for any $\tau>1$, are positively related to $x_{t}^{a} \mathrm{e} v_{t}$. 
In the extreme case of $\omega=0$ it implies that $E_{t}\left[\tilde{x}_{t+\tau}^{a}\right]$ is independent of $x_{t}^{a}$ and then $p_{t}$ may not depend on $x_{t}^{a}$ (OHLSON, 1995, p. 669). Additionally, the functions of $\alpha_{1}(\omega)$ and $\alpha_{2}(\omega, \gamma)$ react in a growing form to its arguments, that is, high values of $\omega$ and $\gamma$ make that $p_{t}$ be more sensible than the achievements of $x_{t}$ and $v_{t}$.

The Ohlson Model also incorporates the properties of Modigliani and Miller (1961) that are: (i) dividends affect market value in a dollar-to-dollar base, thus implying the premise of dividend payment irrelevance; (ii) the dividend paid in the current period negatively influences the expected future income. Together, these two properties indicate that the dividends reduce the $\mathrm{NE}$ book value, but they have no effect on the current income (OHLSON, 1995).

\section{MODEL TESTS}

There are several studies that proposed to test Ohlson Model, that differ in relation to the applied methodology, quality of collected data, establishing of the parameters etc. The reason for such diversity lies in the fact that Ohlson (1995) offered little and sometimes no guidance with regards to the obtaining of some necessary data ${ }^{\mathrm{vi}}$ for the Ohlson Model functionality. Consequently, empirical studies may differ concerning the structuring of the research and therefore, in the results and quality of forecast.

We tried to identify in the academic literature papers that closely evaluate Ohlson's (1995) original model, since there are several papers that use Ohlson Model simply as a fundament and add a series of alterations. In this sense, Ohlson (2000) points out some of these authors in the literature such as Frankel and Lee (1998) and Dechow, Hutton and Sloan (1999).

\subsection{Frankel and Lee (1998)}

Frankel and Lee (FL) study used analysts' income forecast in the OM in order to examine its utility in the stock return forecast ${ }^{\text {vii }}$ in the US. The forecast ability of the model was compared to the amount achieved by the OM operationalization through the use of historical data. The study sought evidence that support the affirmative that analysts' forecast has superior explanatory capability in relation to the income historical data in the OM application $^{\text {viii }}$. In the sample, all non-financial companies in the US were included, with stocks that were negotiated at NYSE, AMEX and NASDAQ. The data has been collected at CRSP, of $\mathrm{I} / \mathrm{B} / \mathrm{E} / \mathrm{S}$ and on COMPUSTAT ${ }^{\mathrm{ix}}$ files.

FL used income forecast data in OM operationalization in order to obtain a measure for company value $\left(V_{f}\right)$. The result was compared to the stock return in order to investigate related points regarding its accuracy in the explanation of company's market prices. It was verified that the variable $V_{f}$ is highly correlated with the stock current prices and more than

\footnotetext{
${ }^{\text {vi }}$ Particularly the variable $v$ and the persistence parameters $\omega$ and $\gamma$.

${ }^{\text {vii }}$ Cross sectional data have been considered (cross-sectional) in the analysis and the forecast of stock returns.

viii In FL understanding, this issue lacks empirical research.

${ }^{\text {ix }}$ CRSP (Center for Research in Security Prices), I/B/E/S (Institutional Brokers Estimate System) and
}

COMPUSTAT are providers of financial information, especially North-American.

BBR, Braz. Bus. Rev. (Eng. ed., Online),

Vitória, v. 1, n. 2, Art. 5, p.136 - 150, jun.- dec. 2004

www.bbronline.com.br 
$70 \%$ of price variations are explained, and therefore it is considered as a good proxy for nonfinancial company's stock return in the US.

The evidences found by FL suggest that the company's value estimates based in the RPV should be a relevant starting point for the stock returns forecast. Many valuation models based in accounting data use simple measures to forecast these returns, such as book to price rate $^{x}$. FL determines that higher returns should result in the adoption of a more complete valuation focus, including as an example the analysts' forecast.

\subsection{Dechow, Hutton e Sloan (1999)}

According to Beaver (1999), Dechow, Hutton and Sloan (DHS) approach is well performed and points out relevant issues that include the dimension in which accounting measures may explain future residual income, current prices and future stock returns. While establishing the necessary parameters for the application of OM, DHS define $r$ by the NE average historical return. The persistency parameters $\omega$ and $\gamma$ had a in-depth approach, with variations $^{\mathrm{xi}}$ that include characteristics that are suggested by the accounting and economic analysis.

According to DHS, the persistency in abnormal income is a function of the return rate and the NE growth rate. Thus defined, variable use for the estimate of persistency in the accounting rate of return and of the NE growth will definew. The accounting literature identified a series of factors that affect the persistency of accounting rate of return. Initially, researchers such as Brooks and Buckmaster (apud DECHOW et al., 1999), Freeman et al. (apud DECHOW et al., 1999), have provided evidences that extreme levels of income and accounting rates of return may revert average more rapidly. Thus, it is expected that $\omega$ be lower for enterprises with extreme accounting rates of returns (abnormal). Secondly, DHS point out that it is recognized that special items are recurrent, such as restructuring expenses and write-off of fixed assets should not continue (FAIRFIELD et al., 1996 apud DECHOW et al., 1999). Again, it is expected that $\omega$ be lower for companies with extreme special items levels.

Besides the accounting literature, the economic analysis points out two factors that are expected in the relation with the abnormal income persistency. First, the dividends policy serves as an expected future growth indicator in the NE accounting value. Companies with growth opportunities tend to have lower dividend payment rates (FAZZARI et al., 1988 apud DECHOW et al., 1999 e ANTHONY; RAMESH, 1992 apud DECHOW et al., 1999). Consequently, it is expected that companies with lower payout ratio policies will observe growth in the NE book value in the future, thus resulting in a higher $\omega$. Secondly, DHS emphasizes that a variety of specific factors of a given activities sector should influence the persistency of abnormal income. Particularly, several studies suggest that there is a link between the structure of the economic segment and the company's profitability (SHERER, 1980; AHMED, 1994 apud DECHOW et al., 1999). DHS assumed that the effect of specific factors in the activities segment may be relatively stable, without any noteworthy alterations.

DHS have evaluated the empirical implications of OM taking past empirical tests as valuation models based on the accounting. Such models were considered as special cases of Ohlson Model, differentiating themselves from the assumed premises. The alternative premises of the valuation models were defined, taking into consideration possible values for

\footnotetext{
${ }^{\mathrm{x}}$ Asset Book Value divided by the stock price market.

${ }^{\mathrm{xi}}$ Variations are further commented.

BBR, Braz. Bus. Rev. (Eng. ed., Online),

Vitória, v. 1, n. 2, Art. 5, p.136 - 150, jun.- dec. 2004
}

www.bbronline.com.br 
the persistency parameters. Two of them are related to the polar extremes, or else, 0 and 1 . The remainder is attributed to a historical average of variables that have impact in the fixation of $\omega$; to the suppression of the "other information" variable in the valuation function; and to the historical average of $\gamma$. The data has been extracted from COMPUSTAT, CRSP and from $\mathrm{I} / \mathrm{B} / \mathrm{E} / \mathrm{S}$.

DHS verified that the OM original empirical implications emanated from the dynamic information that describe the formation of abnormal income forecast. The DHS test showed that, despite the descriptive rationality of the dynamic information, simple valuation models that capitalize analyst forecast of income in perpetuity show better explanation of stock prices. A reason for such fact is that investors super estimate the information comprised in the forecast of analysts of income and over evaluate the information contained in the NE current income and book value.

DHS study also emphasizes that the OM offers a useful pattern for the empirical research, since it provides a unified pattern for a large number of valuation models ad hoc that use the NE book value, income and income short term forecast and still, by the fact that some valuation models based in the Dividends Discount Model make unreal premises over the dividends policy ${ }^{x i i}$, Ohson's model focus directly in the abnormal income forecast, thus avoiding to have to estimate the moment of the future dividends payment ${ }^{\text {xiii }}$.

\footnotetext{
${ }^{x i i}$ Kothari e Zimmerman (1995), for example. Assume a dividends payment rate of $100 \%$.

${ }^{\text {xiii }}$ DHS emphasize that, even if the dividends payment forecast is considered in the Clean Surplus relation, the focus is in the abnormal future income forecast and not in the forecast of its components. This simplification incorporates the notion that the dividends payment policy is irrelevant.
} 


\subsection{Model Comparison}

In the academic research over the capital market, there are a number of studies that investigate the capacity of one or more valuation methods generating reasonable market price forecast. In the comparison among alternative models (benchmark), some papers indicate higher explanatory capability of one approach in detriment of another.

In this sense, Kaplan e Ruback (1995) verified that the Discounted Cash Flow $(\mathrm{DCF})^{\mathrm{xiv}}$ capture the main value relevant items in high leverage transactions. They conclude that the DCF estimates work as good as other valuation methods. Frankel and Lee (1996, 1998) found that estimates based in the residual income and that explain the variations of stock prices are more efficiently than some others. Bernard (1995) encouraged tests to verify the capacity of Dividends Discount Model and of the valuation model from the residual income to explain the stock price variation and achieved the results that indicate the primacy of the latter model. On the other hand, Myers (1999) alleges that Ohlson Model does not offer explanatory capabilities above the approach that only takes into consideration the net equity book value.

Penman e Sougiannis (1998) and Francis et al. (2000) have compared the capacity of the valuation models to explain the stock price. In the former study he provided empirical evidences by using samples of the portfolios and of estimates based in realized values (ex post). Francis et al. (2000) based his studies in samples of individual firms and forecasts of estimated values (ex ante) $)^{\mathrm{xv}}$. Both studies examined dividends models, cash flow and residual income. They have agreed that different models produce results that are equivalent to the valuation model in an infinite horizon forecast; however they concluded that the result is different when infinite series are cut off. The details of such studies are shown hereunder.

\subsubsection{Penman e Sougiannis (1998)}

Penman e Sougiannis used the valuation based in averages of realized values (ex post) in order to compare with market prices ex ante and discovered an error in each valuation technique. The analyzed period covered the years from 1973 to 1990 and data from COMPUSTAT Annual and Research Files that cover the companies listed in NYSE, AMEX and NASDAQ. Financial companies have not been included in the sample. Table $1^{\mathrm{xvi}}$ presents the data related to the valuation errors:

\footnotetext{
xiv Kothari (2001) asserts that the discounted cash flow is a standard valuation model in the finance and economic literature. On the other hand, Copeland et al. (2000) argue that "cash is what matters" and that the cash flow model captures all important elements to valuate an investment. A more detailed analysis of the cash flow model structuring transcends the purposes of this paper. There is an ample literature over this theme that comprises Damodaran (1999), Copeland et al. (2000), among others.

${ }^{\mathrm{xv}}$ In accordance to Francis et al. (2000), the distinction between forecast and realized is noteworthy, since the accomplishment have unpredictable components (arising from factors such as Clean Surplus ratio) which may confuse the comparison of the valuation models that are based on expectations.

${ }^{x v i}$ Adjusted to Table 1 of Penman e Sougiannis study (1998).
}

BBR, Braz. Bus. Rev. (Eng. ed., Online),

Vitória, v. 1, n. 2, Art. 5, p.136 - 150, jun.- dec. 2004

www.bbronline.com.br 


\section{TABLE 1}

\section{Valuation Errors (DDM, DCF and Residual Income) - Selected Horizons}

\begin{tabular}{|c|c|c|c|c|c|c|}
\hline & & & Horizo & $t+\tau)$ & & \\
\hline & $t+1$ & $t+2$ & $t+4$ & $t+6$ & $t+8$ & $t+10$ \\
\hline Panel A - No Ter & & & & & & \\
\hline DDM & 0,923 & 0,845 & 0,663 & 0,478 & 0,283 & 0,069 \\
\hline & $(0,006)$ & $(0,008)$ & $(0,016)$ & $(0,021)$ & $(0,036)$ & $(0,045)$ \\
\hline DCF & 1,937 & 1,868 & 1,762 & 1,670 & 1,552 & 1,450 \\
\hline & $(0,057)$ & $(0,058)$ & $(0,066)$ & $(0,078)$ & $(0,086)$ & $(0,099)$ \\
\hline Residual income & 0,175 & 0,176 & 0,103 & 0,038 & $-0,028$ & $-0,120$ \\
\hline & $(0,013)$ & $(0,013)$ & $(0,019)$ & $(0,021)$ & $(0,027)$ & $(0,039)$ \\
\hline
\end{tabular}

Panel B - With Terminal Value and with Growth Rate

$\begin{array}{lrrrrrr}\operatorname{DDM}(g=0) & 0,574 & 0,504 & 0,314 & 0,132 & -0,061 & -0,295 \\ & (0,029) & (0,039) & (0,042) & (0,053) & (0,050) & (0,055) \\ \text { DCF }(g=0) & 1,254 & 1,188 & 1,112 & 0,946 & 0,782 & 0,827 \\ & (0,184) & (0,155) & (0,142) & (0,251) & (0,222) & (0,353) \\ \text { Residual Income }(g=0) & 0,206 & 0,192 & 0,083 & 0,037 & 0,008 & -0,164 \\ & (0,045) & (0,039) & (0,061) & (0,073) & (0,073) & (0,092)\end{array}$

Panel C-Com Valor Terminal e Taxa de Crescimento de 4\%

\begin{tabular}{lrrrrrr}
$\operatorname{DDM}(g=0,04)$ & 0,424 & 0,356 & 0,167 & $-0,010$ & $-0,203$ & $-0,452$ \\
& $(0,043)$ & $(0,059)$ & $(0,058)$ & $(0,070)$ & $(0,064)$ & $(0,073)$ \\
$\operatorname{DCF}(g=0,04)$ & 0,918 & 0,853 & 0,765 & 0,558 & 0,378 & 0,506 \\
& $(0,269)$ & $(0,224)$ & $(0,199)$ & $(0,424)$ & $(0,342)$ & $(0,560)$ \\
Residual Income $(g=0,04)$ & 0,058 & 0,049 & $-0,061$ & $-0,099$ & $-0,117$ & $-0,307$ \\
& $(0,054)$ & $(0,046)$ & $(0,073)$ & $(0,086)$ & $(0,087)$ & $(0,108)$ \\
\hline
\end{tabular}

Remarks:

- Portfolio Average Standard Deviation in Parenthesis;

- Valuation Error was considered as being the real market value of portfolio in the period $(t+\tau)$ less the precification model, in relation to real market value of the portfolio in the period $(t+\tau)$;

- " $g$ " is the growth rate applied to the period that surpasses the explicit forecast (that is, in the case of a terminal value).

The study concluded that the approach using the Residual Income is better that the valuation models used in the comparison. 


\subsubsection{Francis et al. (2000)}

The data used in the study were from COMPUSTAT, of CRSP and of Value Line. The comparison assumed some premises in relation to the terminal value by adopting two measures for each valuation model. The first specification determines that there is no growth $(g=0)$ after the explicit forecast period (which is of 5 years in the study). The second specifies a growth rate of $4 \%(g=0,04)$, which is consistent to previous studies ${ }^{\text {xvii }}$ (KAPLAN; RUBAK, 1995; PENMAN; SOUGIANNIS, 1998).

TABLE 2 replicates the results achieved from the study and was adapted to Table 1 of Francis et al. (2000, p. 55):

\section{TABLE 2 \\ Sample Forecast Errors (trend) ${ }^{\mathrm{a}}$}

\begin{tabular}{|c|c|c|c|c|}
\hline & Average & $\begin{array}{l}\text { Difference } \\
\text { \% Average }\end{array}$ & Mean & $\begin{array}{c}\text { Difference } \\
\% \text { Mean }\end{array}$ \\
\hline Current Market Price & 31,27 & $\mathrm{n} / \mathrm{a}^{\mathrm{b}}$ & 25,12 & $\mathrm{n} / \mathrm{a}$ \\
\hline
\end{tabular}

Panel A: With Terminal Value and No Growth

Estimate Value

$\begin{array}{lcccc}\operatorname{DDM}(g=0) & 7,84 & -75,5 \% & 5,78 & -75,8 \% \\ \operatorname{DCF}(g=0) & 18,40 & -31,5 \% & 13,79 & -42,7 \% \\ \text { Residual Income }(g=0) & 22,04 & -20,0 \% & 17,91 & -28,2 \%\end{array}$

Panel B: With Terminal Value and Growth of 4\%

$\begin{array}{lcccc}\operatorname{DDM}(g=0,04) & 10,21 & -68,0 \% & 7,44 & -68,7 \% \\ \operatorname{DCF}(g=0,04) & 30,02 & 18,2 \% & 22,93 & -8,8 \% \\ \text { Residual Income }(g=0,04) & 24,16 & -12,7 \% & 19,37 & -22,9 \%\end{array}$

${ }^{a}$ The TABLE shows identified forecast errors to the Average and Sample. The forecast error was computed by ((Forecast Value - Observed Value) / Observed Value).

${ }^{b}$ n/a: non applicable.

TABLE 2 shows the average and mean stock prices at the valuation date, besides the sample estimate values through the DDM, DCF e Residual Income. The presented statistics show that all models tend to under estimate the stock prices. For the test that assumed no growth, the Average has signaled forecast errors of $-75,5 \%$ for the DDM; $-31,5 \%$ for the DCF

\footnotetext{
${ }^{x v i i}$ The growth rate is sometimes assumed equal to the inflation rate (FRANCIS et al., 2000).

BBR, Braz. Bus. Rev. (Eng. ed., Online),

Vitória, v. 1, n. 2, Art. 5, p.136 - 150, jun.- dec. 2004

www.bbronline.com.br
} 
and $-20,0 \%$ for the Residual Income. The mean forecast errors in this same test have showed $75,8 \%$ for the DDM; $-42,7 \%$ for the DCF e $-28,2 \%$ for the Residual Income.

At last, Francis et al. Have established a link for the study of Penman and Sougiannis and concluded that both models came to the same result with regards to the trend comprised in the forecast errors (with respect to the analyzed portfolio): the Residual Income has an lower trend (in absolute terms) than the DCF or DDM estimates.

\section{CONCLUSIONS}

This paper attempted to analyze Ohson's Model empirical testability, and the work consisted of identifying the model's fundaments (raising the subjacent theory), postulating the required inputs and at last, pinpointing the empirical studies that meant to test the model. In the discussion, several points have been identified and debated. Part of them may be found hereunder for verification purposes:

1. The valuation formulae presented by the RPV and OM are valid, however its applicability and empirical testability are limited due to the lack of consistent proxies that may capture the persistency and previsibility of the institution's future income.

2. There is no consensus in the academic literature over the appropriate method to measure the persistency parameters $(\omega$ and $\gamma)$.

3. Doubts as to the appropriate way of capturing the parameters $\omega$ and $\gamma$, and the variable $(v)$ prevents verification of the effective explanatory capabilities of the Ohlson Model. Even if some alternatives can be suggested, they are not a unanimity among researchers and the conclusions are controversial. In failing to provide any formal guidance as to how to decipher the model, Ohlson left no means of being able to refute his ideas. It is widely accepted among researchers that irrefutable ideas, no matter how interesting, are more akin to metaphysics than science (RAPHAEL, 1998). For anything to be qualified as knowledge, it must be open to scrutiny and the risk of being refuted by the most rigorous of its possible critics.

\section{REFERENCES}

ANG, A.; LIU, J. A Generalized Earnings Model of Stock Valuation. Working Paper, Stanford University, 1998.

BEAVER, W. H. Comments on "An Empirical Assessment of the Residual Income Valuation Model". Journal of Accounting and Economics, v. 26, p. 35-42, 1999.

BERNARD, V. L. The Feltham-Ohlson Framework: Implications for Empiricists.

Contemporary Accounting Research, v. 11, p. 733-747, 1995.

BEUREN, I. M. (Org.). Como Elaborar Trabalhos Monográficos em Contabilidade:

Teoria e Prática. São Paulo: Atlas, 2003.

BODIE, Z.; MERTON, R. C. Finanças. 1. ed. rev. ampl. Porto Alegre: Bookman Editora, 2002. 
CERVO, A. L.; BERVIAN, P. A. Metodologia Científica: Para Uso dos Estudantes Universitários. São Paulo: McGraw-Hill do Brasil, 1983.

COPELAND, T.; KOLLER, T.; MURRIN, J. Avaliação de Empresas "Valuation". São Paulo: Makron Books, 2000.

DAMODARAN, A. Avaliação de Investimentos: ferramentas e técnicas para a determinação do valor de qualquer ativo. Rio de Janeiro: Qualitymark, 1999.

DECHOW, P. M.; HUTTON A. P.; SLOAN R. G. An Empirical Assessment of the Residual Income Valuation Model. Journal of Accounting and Economics, v. 26, p. 1-34, 1999.

FERNÁNDEZ, P. Company Valuation Methods: The Most Common Errors in Valuations. [S.1.]: Social Science Research Network, 2001. Available at: <http://papers.ssrn.com>. Access at: 19 out. 2003.

FRANCIS, J.; OLSSON, P.; OSWALD, D. Comparing the accuracy and explainability of dividend, free cash flow, and abnormal earnings equity value estimates. Journal of Accounting Research, v. 38 (Spring), p. 45-70, 2000.

FRANKEL, R.; LEE, C. M. C. Accounting Diversity and International Valuation. [S.1.]: Johnson School Cornell University, 1996. Available at: <http://www.johnson.cornell.edu/nav/wrapper.cfm?page=http://parkercenter.johnson.cornell.e du/\&title=Parker\%20Center $>$. Access at: 10 jan. 2003, 17:09:07.

Accounting Valuation, Market Expectations, and Cross-Sectional Stock

Returns. Journal of Accounting Economics, v. 25, p. 283-319, 1998.

FUKUI, Y. A Data Admissible Ohlson Model. [S.1.]: Social Science Research Network, 2001. Available at: <http://papers.ssrn.com/sol3/papers.cfm?abstract_id=289039>. Access at: 11 dez. 2002, 17:50:27.

HOPPEN, N.; LAPOINTE, L.; MOREAU, E. Um Guia para Avaliação de Artigos de Pesquisas em Sistemas de Informação, [S.1.]: Revista Eletrônica de Administração, 1996. Available at: <http://read.adm.ufrgs.br/read03/read03.htm>. Access at: 14 mar. 2003, 10:37:12.

KOTHARI, S. P. Capital Markets Research in Accounting. Journal of Accounting and Economics, v. 31, p. 105-231, 2001.

KAPLAN, S.; RUBACK, R. The Valuation of Cash Flow Forecasts: An Empirical Analysis, Journal of Finance, v. 50, 1059-1093, 1995.

KOTHARI, S. P.; ZIMMERMAN, J. Price and Return Models. Journal of Accounting and Economics, v. 20, p. 155-192, 1995.

LEE, C. M. C. Accounting-Based Valuation: impact on business practices and research. Accounting horizons, v. 13 (4), p. 413-425, 1999.

LO, K.; LYS, T. The Ohlson model: contribution to valuation theory, limitations, and empirical applications. Journal of Accounting, Auditing and Finance, v. 15, (Summer), p. 337-67, 2000.

LOPES, A. B. A Relevância da Informação Contábil para o Mercado de Capitais: o modelo de Ohlson aplicado à Bovespa. 1v. 308p. Tese (Doutorado em Controladoria e Contabilidade). Universidade de São Paulo, 2001. 
LUNDHOLM, R. J. A Tutorial on the Ohlson and Feltham/Ohlson Models: Answers to some Frequently Asked Questions. Contemporary Accounting Research, v. 11, p. 749-761, 1995.

MCCRAE, M.; NILSSON, H. The Explanatory and Predictive Power of Different Specifications of the Ohlson (1995) Valuation Models. The European Accounting Review, v. 10, n. 2, p. 315-341, 2001.

MODIGLIANI, F.; MILLER, M. H. Dividend Policy, Growth, and the valuation of shares. The Journal of business, v. 34, n. 4, p. 411-433, 1961.

MYERS, J. N. Implementing Residual Income Valuation with Linear Information Dynamics. The Accounting Review , v. 74, p. 1-28, 1999.

OHLSON, J. A. Earnings, Book Values, and Dividends in Equity Valuation. Contemporary Accounting Research, v. 11, p. 661-687, 1995.

PENMAN, S. H.; SOUGIANNIS, T. A Comparison of Dividend, Cash Flow, and Earnings Approaches to Equity Valuation. Contemporary Accounting Research, v. 15, n. 3, fall, p. 343-383, 1998.

PLENBORG, T. Firm Valuation: Comparing the residual income and discounted cash flow approaches. [S.1.]: Social Science Research Network, 2000. Available at: <http://papers.ssrn.com>. Access at: 30 out. 2002, 08:54:20.

RAPHAEL, F. Popper: O Historicismo e sua Miséria. São Paulo: UNESP, 1998.

RICHARDSON, R. J. Pesquisa Social: Métodos e Técnicas. 3 ed. São Paulo: Atlas, 1999. 